\title{
COMIDA, AGÊNCIA E IMITAÇÃO: \\ UMA ETNOGRAFIA DAS FESTIVIDADES ENTRE IMIGRANTES \\ BRASILEIROS NA GRANDE BOSTON
}

\author{
Viviane Kraieski de Assunção ${ }^{1}$
}

\section{Introdução}

De acordo com Renato Ortiz, havia uma concordância entre antropólogos, historiadores e geógrafos sobre a territorialidade das culturas, que afirmavam que as práticas alimentares se moldam no espaço. A modernidade, entretanto, contrariou esta fixidez, pois se caracteriza pela mobilidade. "A alimentação deixa de ser um universo ao abrigo da fragmentação e da rapidez do mundo moderno" (Ortiz, 1994: 79). Por isso, estudiosos passaram a considerar a internacionalização dos comportamentos alimentares. O autor lembra que, anteriormente, a alimentação revelava e preservava os costumes, localizando-os em suas respectivas culturas, e traduzia ainda a estabilidade do grupo social. Teorias sobre a modernização dos países "subdesenvolvidos", que estavam em voga principalmente nas décadas de 1950 e 1960, destacam esta fixidez das práticas alimentares, considerando-os como "barreiras culturais para a mudança" e “obstáculos ao progresso" (Ortiz, 1994:77).

Os imigrantes constituem grupo privilegiado para o estudo desta possível fixidez ou internacionalização da alimentação. Com esta perspectiva, realizei uma etnografia das mudanças e continuidades das práticas alimentares de imigrantes brasileiros na Grande Boston. Minha pesquisa foi concentrada na alimentação cotidiana de meus sujeitos de pesquisa, buscando compreender as possíveis transformações e/ou reproduções de suas práticas que ocorrem no dia-a-dia destes brasileiros.

A ideia de realizar uma pesquisa sobre as práticas alimentares de imigrantes brasileiros no exterior ocorreu inicialmente devido a minhas relações de parentesco. Minha irmã e meu cunhado migraram para a Grande Boston em 2001, e lá permaneceram por dez anos. Por meio deste vínculo familiar, e por já haver realizado pesquisa sobre alimentação no mestrado, notei que a alimentação poderia se constituir em uma via de leitura sobre a experiência de ser um(a) imigrante brasileiro(a) nos

\footnotetext{
${ }^{1}$ UNESC, Brasil. Email: vivianekraieski@gmail.com ORCID id: https://orcid.org/0000-0003-0118-2486
} 
Estados Unidos. Através de suas falas, pude visualizar um rico cenário de pesquisa: o estranhamento com o gosto do café servido em fast foods, os almoços em restaurantes de comidas brasileiras, o lanche servido após as missas em Igrejas Católicas, a dificuldade em encontrar certos produtos em supermercados, o transporte de comidas nas malas durante a viagem, o envio destes alimentos pelo correio por seus familiares... Foi também por meio destes laços de parentesco que evidenciei a importância das redes sociais dos migrantes. Aliás, para realizar meu trabalho de campo, eu mesma me inseri (e fui inserida) em redes de relacionamento - inicialmente, por informações e contatos de minha irmã e de meu cunhado, e, posteriormente, por indicações de outros sujeitos.

Assim, por sete meses, convivi com imigrantes brasileiros, realizei entrevistas informais (algumas gravadas, outras não), fui a restaurantes, padarias e mercados brasileiros, acompanhei brasileiros a compras em supermercados americanos ${ }^{2}$, participei de festas e almoços. Realizei ainda trabalho voluntário no Centro do Imigrante Brasileiro (CIB). Lá, acompanhando o trabalho de outros voluntários e conversando com os imigrantes que procuravam o CIB em busca de todo o tipo de ajuda (problemas de acesso à rede de saúde, falta de documentação, exploração no trabalho, o não-pagamento de salários, violência conjugal, problemas de acesso aos serviços do Consulado brasileiro, entre outros), pude perceber melhor as dificuldades e necessidades enfrentadas por quem migra e vive indocumentado nos Estados Unidos.

Neste texto, eu me concentrarei nos momentos de festividade, que, embora não sejam cotidianos, são recorrentes e marcam as experiências de meus interlocutores na Grande Boston. Busco compreender as práticas alimentares destes eventos por meio dos conceitos de agência (Gell, 1998) e mímesis (Taussig, 1993), assumindo, deste modo, o papel preponderante da comida nestes momentos. Além disso, são utilizados outros aportes teóricos para lançar interpretações sobre as variadas formas como a comensalidade está estritamente relacionada aos vínculos sociais entre os sujeitos.

\section{A heterogeneidade do universo de pesquisa}

Os Estados Unidos são o principal destino dos emigrantes brasileiros. Segundo o IBGE, que pesquisou pela primeira vez o número de emigrantes brasileiros no Censo de 2010, há 491.243 brasileiros residentes em 193 países do mundo, sendo que, deste total,

\footnotetext{
${ }^{2}$ Utilizo, ao longo deste texto, o termo "americano" para me referir aos estadunidenses de modo geral, seguindo o uso recorrente da palavra por meus sujeitos da pesquisa.
} 
23,8\% vivem nos Estados Unidos. Estes números, no entanto, são controversos, já que há um grande contingente de indocumentados. Um estudo anterior estimou que, só nos Estados Unidos, haveria entre 800 mil e 1,4 milhão de brasileiros, sendo que a maior concentração - 24\%, o que corresponde a 336.000 pessoas - estaria no Estado de Massachusetts (Lima, 2009).

Durante minha pesquisa de campo, pude perceber a heterogeneidade dos brasileiros na Grande Boston. Ainda que possa ser verificado um grande número de mineiros, conheci brasileiros provenientes de diversos Estados brasileiros. Eram de diferentes faixas etárias - variando de 22 a 65 anos -, e níveis de escolaridade - desde brasileiros com pouca educação formal até aqueles que concluíram o ensino superior. Tinham também diferentes tempos de permanência nos Estados Unidos e status migratório - brasileiros indocumentados, com visto de estudante, Green Card (residente permanente legal) e até mesmo com dupla cidadania (brasileira e americano) -, mas os que lá viviam indocumentados e que tinham migrado após o ano 2000 eram visivelmente mais numerosos. Esses brasileiros tinham em comum o fato de terem ido para os Estados Unidos a partir do contato com outros brasileiros, com quem tinham laços de parentesco ou de amizade, o que evidencia que fazem parte de redes sociais (Boyd, 1989; Massey, 1990).

Ainda que eu tenha encontrado brasileiros com diferentes motivações para migrar, a maioria tinha ido para os Estados Unidos com a intenção de passar um período de tempo (em torno de quatro anos) e retornar para o país após realizarem seu projeto migratório, como o de comprar uma casa própria, montar um negócio ou pagar os estudos dos filhos. Nesse sentido, concordo com Sayad (1998) sobre a dupla contradição que muitos emigrantes vivem: o estado provisório da emigração e o prolongamento da condição de emigrante por tempo indeterminado.

Todos os interlocutores da pesquisa trabalhavam em funções ocupadas por migrantes com pouca ou nenhuma qualificação profissional: serviços de limpeza de casa (como housecleaner e housekeeper) ${ }^{3}$, jardinagem (landscaping), delivery (trabalhos de entrega em domicílio, principalmente de comidas e jornais), trabalhos em cozinhas de restaurantes e na construção civil. Os imigrantes provenientes de camadas médias no

\footnotetext{
${ }^{3}$ Housecleaner pode ser traduzido como faxineira ou diarista, que realiza eventuais trabalhos de limpeza em casas. Já housekeeper pode ser traduzido como empregada doméstica, que trabalha diariamente em apenas uma casa ou para somente uma família.
} 
Brasil experienciavam, nas funções ocupadas nos Estados Unidos, um movimento descendente de status, realizando trabalhos de pouco prestígio social. Como comentou uma de minhas interlocutoras, "aqui não vale o diploma nem o dinheiro", pois, segundo ela, o status social é definido pela situação migratória, já que os maiores privilégios como a possibilidade de vir ao Brasil e voltar para o país -, são daqueles que vivem legalmente nos Estados Unidos.

Ainda que relatem um aumento nos ganhos financeiros nos Estados Unidos, esses imigrantes experienciam muitas dificuldades, especialmente os indocumentados: árdua rotina de trabalho, exploração dos empregadores, ameaças de deportação, pouco ou nenhum conhecimento da língua inglesa, falta de acesso ao sistema de saúde, além da saudade de familiares e amigos que permaneceram no Brasil.

Se antes os brasileiros nos Estados Unidos eram descritos como comunidade invisível (Margolis, 1998), sua presença na Grande Boston pode ser percebida de diversas formas, como nos mercados étnicos, nas igrejas, nos jornais e nas rádios brasileiras, e em sua em algumas cities e towns, como Everett, Sommerville, Allston e Framingham, alterando a sua paisagem (Marcus, 2009). Como afirmavam meus interlocutores, era possível encontrar "tudo do Brasil”, o que possibilitava reproduzir muitas das práticas alimentares que mantinham antes da migração para os Estados Unidos ${ }^{4}$.

\section{Comidas em Festas: agência e imitação}

Durante a realização do trabalho de campo, pude acompanhar meus interlocutores em diferentes momentos de festividade e comensalidade: festas de aniversário, churrascos nos finais de semana, festivais brasileiros, refeições e festas em Igrejas, entre outros. Embora eu não caracterize estes momentos como eventos cotidianos, isto não significa que sejam raros: a vida social de meus interlocutores mostrou-se bastante intensa, com a organização e o recebimento de convites para encontros e festividades.

As festas realizadas por e para imigrantes brasileiros são aqui entendidas como resultados dos fluxos culturais globais, que Appadurai $(1996,1999)$ compreende como compostos de cinco panoramas disjuntivos: tecnopanoramas, finançopanoramas,

\footnotetext{
${ }^{4}$ Sobre as continuidades e descontinuidades destas práticas alimentares, ver Kraieski (2015).
} 
ideopanoramas, etnopanoramas e midiapanoramas. Embora todos estejam interligados, os dois últimos - etnopanoramas e midiapanoramas - relacionam-se de forma mais direta às composições destas festas. Os primeiros tratam dos fluxos de pessoas pelo mundo, como turistas e imigrantes, além de refugiados e exilados; o segundo, da distribuição das capacidades eletrônicas de produzir e disseminar informações através de jornais, revistas, canais de televisão, filmes etc., além de um grande "repertório de imagens, de narrativas e de etnopanoramas para os espectadores do mundo inteiro..." (Appadurai, 1999: 315). A partir desta perspectiva, as festas ocorridas em Boston são abordadas a partir das tensões destes fluxos culturais de pessoas e imagens que extrapolam fronteiras nacionais.

As festas e celebrações podem também ser entendidas através de linhas teóricas que têm como base os escritos clássicos de Durkheim e outros membros da Escola Sociológica Francesa. A partir desta linha interpretativa, estes eventos apresentam papel preponderante na coesão de grupos, pois, através de sua "efervescência", promovem e reforçam um sentimento de pertencimento social. Deste modo, nas festas e celebrações, é a própria sociedade que está sendo comemorada e (re)feita. Apesar de ser possível entender estas reuniões sociais como momentos de fortalecimento e criação de laços sociais, ressalto que há também possibilidades de encontrarmos não apenas coesão e consenso, mas inúmeras divisões e tensões, que marcam diferenças entre classes e status social, e através das quais podem ser percebidas inclusões e distinções entre brasileiros.

Nas inúmeras festas que pude comparecer em Boston, a comida parecia ser grande preocupação daqueles que organizavam e preparavam os eventos, e também um dos focos de atenção dos participantes. Nas festas realizadas em datas comemorativas em uma Igreja Católica, por exemplo, a primeira e principal decisão a ser tomada pelos organizadores era qual comida seria servida. A partir desta, seguiam-se as demais: quem prepararia a comida, se os participantes comprariam convites ou de que formas o dinheiro seria arrecadado, em qual local seria a festa, entre outras. Ainda que não haja consenso sobre o que é "comida brasileira", e que esta denominação comporte uma grande variedade de comidas, a comida em festas surge com papel simbólico, "como expressão de um código culinário voltado para o grupo familiar e como expressão de uma unidade social mais ampla, aparecendo como código ideal, unificador, em oposição à sociedade real" (Alves, 2005). Desta forma, as relações entre brasileiros, assim como 
as relações entre estes e americanos e/ou outros imigrantes, que são possibilitadas por estas festas, podem ser evidenciadas por meio do compartilhamento ou não deste código culinário.

Mas, para além de seu conteúdo simbólico, sugiro que a comida pode expressar intencionalidade e agência, tal como proposto por Daniel Miller (1987) e Alfred Gell (1998). Para Gell (1998), as coisas são dotadas de agência social, pois esta pode ser exercida tanto em relação às coisas, como também por coisas. Seu conceito de agência é contextual e relacional, pois, para que algo ou alguém seja agente, é preciso que este seja capaz de produzir ou dar início a eventos causais ao seu redor. A agência humana, segundo Gell, só é possível inserida em um mundo material, e é exercida através de diversas formas de mediações físicas. Deste modo, as coisas não apenas representam algo, mas tornam este algo presente, pois carregam significados e valores que estão contidos em sua materialidade - no caso da comida, podemos acrescentar sua sensorialidade, especialmente o gosto e o cheiro, tão ressaltados por meus sujeitos de pesquisa. Assim, as comidas não somente representam as lembranças dos imigrantes, marcadas pela saudade, como o convívio familiar e os momentos de festividade da localidade onde nasceram, como também têm o poder de carregar estas lembranças.

A comida, portanto, possui agência e intencionalidade sobre o tempo, o espaço e os sujeitos com os quais se relaciona. Neste sentido, a comensalidade não é pensada aqui apenas como o consumo de comidas e bebidas e as regras que reforçam as relações sociais através do consumo. Mais do que isso, a comensalidade é uma troca sensorial de memórias e emoções, e do consumo de substâncias e objetos que carregam estas lembranças e sentimentos (Seremetakis, 1993: 14). Porém, ainda que a materialidade da comida, com seus sabores e odores, sejam capazes de trazer lembranças aos brasileiros em Boston, meus interlocutores, quando entrevistados ou em conversas informais durante festas, eram praticamente unânimes em afirmar que, embora fossem semelhantes aos do Brasil, as comidas e festas não eram iguais. "É bom, mas não é a mesma coisa", disse-me uma amiga de uma interlocutora durante a festa junina na paróquia de Everett.

A partir destas afirmações, proponho-me a pensar as comidas das festas (e por que não as próprias festas) como mímesis. Baseado em leituras de Frazer e Benjamim, Taussig define mímesis como a natureza que a cultura utiliza para criar uma segunda natureza. É ainda a faculdade de imitar, criar modelos, explorar a diferença e de se transformar em "outro". Citando Benjamim, o autor afirma que "a habilidade de imitar, 
e imitar bem, é, em outras palavras, a capacidade para [tornar-se] Outro" (Taussig, 1993:19; tradução minha). Nas palavras do autor, a cópia carrega as características e o poder do original. No entanto, não é um mero produto do original, mas possui as propriedades daquilo que é imitado, o que lhe confere a possibilidade de afetá-lo. Taussig, através da obra de Frazer (o clássico O Ramo Dourado), afirma que ver e ouvir algo é estar em contato com este algo, sendo, deste modo, cópia e contato elementos de um mesmo movimento. Explorando as concepções de Frazer sobre mágica simpática, Taussig extrai as distinções do autor sobre dois tipos de mágica: as que ocorrem por meio da similaridade, e as que necessitam de contato. A partir destas concepções, percebe-se que não ocorre mágica apenas através da similaridade visual - o parecer o “outro" - mas também através dos elementos a partir das quais ela é produzida.

Pensando na comida, podemos ampliar esta concepção de Taussig, afirmando que comer algo é também entrar em contato. Ainda que não seja igual e é reconhecidamente inferior ao original, a comida carrega o poder de estar em contato com aquilo que se pretende imitar ou tornar presente. A mímesis é, portanto, a capacidade de se tornar o outro, indo em direção a ele. Desta maneira, através do processo da mímesis, procura-se superar a distância entre si mesmo e o “outro".

No entanto, este processo não produz puramente uma cópia, pois implica também transformações e alterações que ocorrem no ato em que se imita. Como afirmavam meus interlocutores, apesar da semelhança, a comida e as festas não eram iguais às do Brasil. Ainda assim, esta similaridade traz as lembranças do Brasil. O fato de ser diferente confere mais poder às comidas e festas originais brasileiras que se pretende imitar, e que continuam sendo consideradas superiores e melhores.

Além de trazerem lembranças, o consumo de comidas e a participação em festas são também oportunidades para conhecer o(s) “outro(s)". Neste caso, a comensalidade constitui-se em uma importante ferramenta para americanos, imigrantes de outras nacionalidades, como também brasileiros provenientes de diferentes localidades, entrarem em contato e estabelecerem uma forma de conhecimento do "outro". É também um momento importante de transmissão cultural que ocorre de imigrantes brasileiros para seus filhos, nascidos nos Estados Unidos ou levados para lá ainda crianças.

Aqui podemos entender este processo de conhecimento através das comidas e das festas também a partir do conceito de mímesis de Taussig. Tendo como base a obra 
de Benjamin, o autor argumenta que toda forma de conhecimento é corporal e sensorial, pois no ato de imitação há uma compreensão do "outro" que se processa através dos corpos. Através deste conhecimento, ocorrem também (re)produções de alteridade. A antropóloga Elsje Lagrou (1998) nota que a percepção estética ou sensorial é usada como marcador de diferenças entre grupos sociais. Estes se diferenciam, de acordo com a autora, a partir do que gostam, coerentes com seus entendimentos sobre estética e gosto, que estão relacionados a valores e julgamentos. Portanto, percepções sensoriais como gosto, cheiro e sons - são passíveis de críticas por outros grupos e tornam-se fundamentais para a construção de identidades sociais.

Antes de tratar sobre as especificidades de algumas festas, discorrerei sobre a sazonalidade do consumo. As divisões temporais tornam-se importantes para compreender a frequência das reuniões sociais, além do consumo relacionado a elas, como demonstro a seguir.

\section{Tempos de festa: inverno e verão}

Cheguei a Boston para realizar meu trabalho de campo no mês de maio, primavera no Hemisfério Norte. Desde minha chegada, muitos imigrantes contaram-me sobre as dificuldades do inverno e, mais especificamente, da neve. Embora vários interlocutores me falassem sobre as belezas do inverno, logo narravam suas inconveniências: o frio intenso, as dificuldades de locomoção, os perigos em dirigir em estradas congeladas e escorregadias - envolver-se em acidentes de trânsito pode significar problemas para os imigrantes indocumentados. Logo percebi que as distinções entre inverno e verão, ou período de frio e calor, respectivamente, eram bastante importantes para dar conta da experiência narrada por imigrantes brasileiros em Boston.

No período de aproximadamente maio a setembro, o período do verão, as pessoas diziam estar mais dispersas. É o período das férias escolares e de se ir às praias na região. Durante este período, o público nas Igrejas é bastante limitado. Na Igreja Batista, os almoços aos domingos tinham sido suspensos até o início do frio, quando a Igreja voltou a ficar cheia. Meus interlocutores contaram-me sobre a tristeza e a depressão que sentem durante o inverno, principalmente quando a paisagem começa a ficar branca devido à neve. Se a saudade é constante durante todos os meses do ano, ela se intensifica neste período. Mas é neste momento em que ocorrem com mais frequência os encontros coletivos, com encontros em casas, como almoços e jantares. Alguns 
trabalhos que os imigrantes realizam na Grande Boston também sofrem variações sazonais. No inverno, as housecleaners têm mais oferta de trabalho, pois, no verão, durante as férias escolares, as famílias mais abastadas costumam viajar e não contratam faxineiras.

As (in)conveniências do frio e, principalmente, da neve no inverno podem também ser pensadas de formas diferenciadas de acordo com a inserção e o status migratório dos brasileiros que vivem na região da Grande Boston. Conheci muitos deles que vivem em situação legal no país, a maioria com tempo de permanência superior a dez anos, que me disseram apreciar os períodos de inverno. Em geral, estes brasileiros possuem lazeres diferenciados daqueles com situação econômica e capital cultural mais desfavorável, como praticar esqui na neve em estados próximos a Massachusetts. Jonas, ${ }^{5}$ que possui cidadania americana, disse-me que as pessoas ficam depressivas no inverno porque "não querem curtir": "Ficam em casa, aí vem o tédio e a depressão." Para ele, "essa diversificação de estações tira você do tédio, tira você do sério, porque renova." Segundo Jonas, "se a pessoa tem uma certa cultura, ela não tem esse problema [depressão] aqui."

O verão é o tempo dos churrascos ao ar livre nas casas dos brasileiros em momentos de folga, especialmente aos domingos. Jonas, por exemplo, tem duas churrasqueiras: uma nos fundos da casa e uma portátil na pia da cozinha. A churrasqueira é de carvão, mas de espeto, e uma pequena é a gás. Segundo ele, os churrascos entre brasileiros são mais comuns em Boston do que em Minas Gerais, de onde migrou, e para onde retorna pelo menos uma vez a cada dois anos. Jonas sugere que em Boston os churrascos também ocorram em casas de pessoas de menor poder aquisitivo, ao contrário do Brasil, onde seria mais comum em camadas médias e altas:

(...) aqui no verão é churrasco quase todos os dias. (...) é mais rápido, é mais prático, você convida um, convida outro, cada um traz um negocio, é assim... você não fica preso ali. Você chega no Brasil, você vai fazer um churrasco, é até curioso... ninguém tem churrasqueira direito... pelo menos, eu tô falando da minha experiência. Aí quando eu vou lá, eles já sabem... as casas do pessoal de poder aquisitivo maior, já tem uma churrasqueira montada, de tijolinho, mas assim, na média, baixa, não é típico... 'ah, acho que fulano tem uma churrasqueira'.

Nos churrascos em Boston, são preparadas carnes e linguiças. Estes são comprados, mais recorrentemente, em açougues brasileiros. Como mencionei anteriormente, os açougues brasileiros vendem carnes imigrantes com "corte brasileiro",

\footnotetext{
${ }^{5}$ Os nomes de todos os interlocutores foram substituídos por nomes fictícios para garantir o anonimato dos sujeitos.
} 
que seria diferente do "corte americano". Já as linguiças brasileiras também são diferenciadas, principalmente em relação ao sabor. Desconhecendo este fato, cometi uma gafe em um dos churrascos que participei organizado por colegas brasileiros, e com participação de norte-americanos, do Centro do Imigrante Brasileiro. Como ficou combinado entre os colegas, cada participante deveria levar um pedaço de carne ou linguiça para ser assado na churrasqueira e partilhado entre os convidados. Devido aos compromissos do trabalho de campo e minhas dificuldades de locomoção por não ter carro, não pude comprar carne em um açougue brasileiro. Então, resolvi levar linguiça italiana, comprada em um supermercado de fácil acesso. Embora o anfitrião tenha me dito, educadamente, que eu tinha feito uma boa compra, após preparada, a linguiça italiana foi servida juntamente com a brasileira, com a recomendação de que experimentássemos ambas. $\mathrm{O}$ alvo principal desta experimentação eram os convidados americanos, e o objetivo era ressaltar a superioridade do sabor da comida brasileira.

Se as carnes podem ser compradas com "cortes brasileiros", o mesmo não se pode dizer das churrasqueiras. Assim como uma grande variedade de comidas consumidas pelos brasileiros, o churrasco "é bom, mas não é igual ao do Brasil". 6 Segundo meus interlocutores, isso se deve à falta de churrasqueiras a carvão e com espetos. Nas churrasqueiras a gás, mais comuns nos Estados Unidos, a carne é preparada em chapas ou grelhas. Conheci a esposa de um brasileiro que trouxe do Brasil uma churrasqueira a carvão, com espetos. Apesar da falta de uma "churrasqueira brasileira" não impedir a realização dos churrascos, ela altera os prazeres sensoriais deste momento de comensalidade. Além disso, altera a forma de preparo, que requer conhecimento diferenciado, incorporado na materialidade das churrasqueiras.

Os relatos de meus interlocutores e minhas observações sobre a vida social dos imigrantes nos períodos de verão e de inverno lembravam-me as descrições de Marcel Mauss em seu "Ensaio sobre as variações sazonais nas sociedades esquimós", de 1906. Ao analisar as sociedades esquimós, Mauss conclui que "a vida social não se mantém no mesmo nível nos diferentes momentos do ano, mas passa por fases sucessivas e regulares de intensidade crescente e decrescente, de repouso e de atividade, de dispêndio e de reparação" (2003: 501). Deste modo, no inverno e no verão "a forma do agrupamento muda, vemos a religião, o direito e a moral transformados do mesmo modo" (2003: 503). Para Mauss, "o movimento que anima a sociedade é sincrônico ao

\footnotetext{
${ }^{6}$ Em outro momento, analiso esta afirmação recorrente entre os sujeitos de pesquisa, realizando uma discussão sobre o gosto como prática (ver Assunção, 2016).
} 
da vida ambiental" (2003: 473). Mauss esclarece que seus estudos são bastante diferenciados das abordagens teóricas do determinismo biológico, que entendem que o ambiente determina o modo como a morfologia social se apresenta de formas distintas nas duas estações (de frio e de calor).

Às análises de Mauss sobre as variações da vida social, podemos incluir observações sobre o consumo dos sujeitos de pesquisa. Em uma abordagem que considera a capacidade dos bens de se prestarem a símbolos que fazem parte de um sistema de comunicação, Douglas e Isherwood analisam a periodicidade do consumo. Para estes autores, a frequência com que consumimos os bens apresenta uma correlação com hierarquias e status social. Neste sentido, os consumidores não são apenas possuidores de bens, como também operam um padrão de periodicidade. Eles destacam que a comida pode oferecer uma discriminação detalhada da periodicidade. "A comida pode discriminar os diferentes períodos do dia, e um dia do outro; assim como pode distinguir os eventos anuais, pode também distinguir os eventos da existência, como funerais e casamentos" (Douglas e Isherwood, 2006: 173).

No entanto, mais do que servir como marcadores de periodicidade, como coloca Appadurai, “o consumo cria o tempo, e não apenas responde a ele” (1996: 70; tradução minha). Segundo o autor, quando a repetição do consumo parece ser determinada por sazonalidades universais ou naturais - o autor se refere aos ritos de passagens, como a puberdade, mas podemos pensar, neste caso, também nas estações de frio e de calor - é preciso considerar também o movimento contrário, no qual as sazonalidades do consumo podem determinar o estilo e a significação das denominadas passagens "naturais" (1996: 70). Para Appadurai, as periodicidades de consumo não constituem apenas marcadores simbólicos de eventos "naturais", mas se constituem na principal significância destes eventos. Conclusão semelhante é feita por Moeran e Skon em pesquisa realizada no Japão. Para os autores, as mudanças de estação são associadas a ciclos de consumo e a imagens, como as do Monte Fuji e do florescimento de cerejeiras, que são usadas como estratégias de mercado para persuadir as pessoas a comprarem determinados produtos (Moeran e Skov, 1997: 189).

Neste sentido, a vida social dos brasileiros em Boston e o consumo que a acompanha (como os churrascos e os almoços em igrejas) não são apenas decorrências das estações do ano, mas participantes da constituição e da significação das mudanças "naturais". Ainda que alguns eventos sejam característicos de determinadas estações do 
ano, outros ocorrem em (e constituem) diferentes periodicidades. É o caso de comemorações que marcam datas festivas, como os aniversários. Detenho-me sobre estas festas nas próximas páginas.

\section{Festas de aniversário}

Minha participação em festas de aniversário de crianças e adultos em Boston, diferentemente de outras ocasiões festivas, ocorreu a partir de meus laços de parentesco: minha inserção em uma rede de amigos na qual minha irmã, meu cunhado e minha sobrinha, então com três anos de idade, faziam parte. $\mathrm{O}$ aniversário de um ano de idade de minha sobrinha, que contou com 90 convidados, rendeu convites para festas de diversas crianças destas redes de amigos nos anos seguintes. Como mostra Clarke, há um efeito bola de neve na formação de um circuito de festas, que se forma nos momentos em que se organiza e se participa de uma festa de aniversário (Clarke, 2007: 267). Concordo também com a autora de que as festas infantis são raramente organizadas como expressões únicas das relações entre pais e filhos, pois fazem parte da socialidade na qual as redes de crianças e presentes transitam em círculos de reciprocidade (Clarke, 2007: 266). O convite e a participação em uma festa geram a ação obrigatória da retribuição do convite na organização de uma festa futura, tal como formulada a teoria do dom por Mauss (2003).

Também de acordo com Clarke, as festas de aniversários de crianças, além de se constituírem em marcadores de idade e passagem do tempo, também são um gênero de consumo, o que pode ser evidenciado através da apropriação de comidas, decoração e outras formas de cultura material (Clarke, 2007). As festas de filhos de imigrantes brasileiros em Boston são decoradas com temas de desenhos animados infantis, como Barbie, Homem Aranha, Dora, The Explorer, entre outros, que fazem parte das imagens das indústrias do entretenimento que circulam globalmente (Appadurai, 1996, 1999). Estes motivos - estampados na decoração do bolo, em copos, guardanapos e toalhas de mesa -podem ser comprados em grandes lojas de departamento locais.

O local da festa varia de acordo com as condições financeiras dos imigrantes e o número de convidados. Algumas festas acontecem em salas próprias para festas que são alugadas pelos imigrantes. Outras ocorrem nas casas e nos apartamentos onde moram os imigrantes, e fui ainda a uma festa realizada em um salão de uma igreja evangélica frequentada pela família da criança aniversariante. É interessante observar que, 
principalmente nos casos em que a festa é realizada em locais pagos, os convites contêm a hora de início e também a de término do evento, o que é incomum em festas de aniversário (e de outras comemorações) que são feitas no Brasil. Os brasileiros, apesar de estranharem esta diferença, passam a adotá-la, especialmente pelas exigências dos contratos de locação das salas.

O horário de início da festa também marca diferenças em relação a participantes de outras origens étnicas. As festas de aniversário de brasileiros são frequentadas majoritariamente por brasileiros, mas algumas delas contam com convidados americanos ou de outras nacionalidades, particularmente os chefes e colegas de trabalho mais íntimos. Os horários do início da festa que constam nos convites para brasileiros são, em geral, uma hora antes do horário de chegada dos convidados desejada por quem está dando a festa. Como me explicaram, isto garante que os brasileiros, que costumam chegar atrasados - uma hora depois da hora do convite - cheguem no horário previsto pelo organizador. Os convites para americanos, por outro lado, contém o horário com uma hora depois da prevista para brasileiros, impedindo que estes cheguem adiantados ao início da festa, pois estes costumam ser pontuais na chegada.

As festas de aniversário nas quais os brasileiros realizam os maiores gastos são, sem dúvida, as que celebram o primeiro ano de vida das crianças. Nestas, a decoração costuma ser mais imponente; o número de convidados, maior. Estas festas apresentamse como formas de apresentação social da criança, e são perceptivelmente direcionadas a adultos (embora haja também a presença de crianças), que fazem parte das redes de relações da família do aniversariante. Nestas festas, as comidas são mais próximas às encontradas em festas infantis realizadas no Brasil: bolo, docinhos e salgadinhos. Os bolos são recheados, decorados com a mesma decoração da festa, e alguns deles contém o nome do aniversariante. Os docinhos são, principalmente, brigadeiros e outros preparados com leite condensado, como beijinho. Os salgadinhos são pastéis, empadinhas e risoles, mas também encontram-se em algumas festas pequenos sanduíches e cachorro-quente. Embora não se constitua em um padrão de todas as festas, na maioria delas é servido um jantar ou almoço, dependendo do horário. Entre as comidas, estão arroz, maionese ou salpicão, farofa e carne, geralmente assada semelhante à comida especial preparada nos almoços de domingo (Woortmann, 1986). Em algumas destas festas não há salgadinhos, mas apenas o bolo e docinhos. Nas festas de aniversário de adultos, geralmente há comida do jantar ou almoço e um bolo. Em um 
dos aniversários em que participei, a comida do jantar foi encomendada em restaurantes brasileiros, e o bolo, docinhos e salgadinhos foram comprados em padarias brasileiras. Há também festas na qual a comida, toda ou parte dela, foi preparada pela família do aniversariante, ou ainda com a participação de amigos, principalmente na preparação dos numerosos docinhos.

Após o aniversário de um ano, os formatos das festas variam. Esta variação depende, em grande parte, do círculo de relações nas quais a criança está inserida. À medida que a criança passa a frequentar escolas nos Estados Unidos, os locais e as comidas das festas sofrem mudanças. Algumas festas infantis são realizadas em escolas, para facilitar a presença dos colegas de classe. Outras são feitas em locais próprios para festas, com grandes brinquedos, como escorregador, balanços, e alguns eletrônicos, como videogames. Nestas festas, são introduzidas outras comidas que raramente estão presentes nas festas de aniversário de brasileiros, como pizzas, cupcakes e hot dogs, apesar de algumas delas também terem docinhos e salgadinhos.

Quando as festas são realizadas nas escolas ou nestes espaços visando à presença destes colegas, frequentemente é realizada uma outra festa para a participação de familiares, parentes e amigos mais próximos. Esta outra festa é geralmente um almoço ou jantar, no sábado ou domingo próximo ao aniversário da criança, com comidas, como as citadas acima, além de bolo e doces. Foi como me explicou Monica, avó de um menino de quatro anos nascido nos Estados Unidos: "Um e dois anos foi muita festa. Bolo, torta, muito doce... Três anos já foi num lugar que ela só leva o bolo, a pizza e o suquinho (naquele lugar, pra brincar). E à noite é feita a festa em casa. Bolo, doce, aí vêm as crianças outra vez, e os adultos.”

As festas de aniversário constituem, portanto, eventos de socialização dos filhos. Segundo Otnes e al., as mães se utilizariam de roteiros, performances e artefatos rituais das festas infantis para ensinar às crianças sobre conhecimento geral, valores e comportamentos específicos necessários para a participação bem-sucedida neste ritual (Otnes et al. 1995 apud Clarke, 2007: 270-271). Segundo os autores, que realizaram pesquisa na América do Norte, alguns destes atos de socialização envolviam ensinar às crianças que certos temas comerciais de festas, considerados agressivos, são inaceitáveis. O que vemos em relação aos brasileiros é que as festas de aniversário de seus filhos os inserem nas - e evidenciam as - redes de sociabilidade que são fundamentais para a vida das crianças, privilegiando tanto as redes de amizade formadas no ambiente escolar, onde há a presença maior de americanos, quanto as redes de 
parentesco, composta por familiares e parentes brasileiros. Nestas festas, a comida varia de acordo com os convidados que são esperados.

As muitas fotografias feitas nestas festas são rapidamente postadas em sites de relacionamento, populares entre os brasileiros. Esta postagem é feita no dia seguinte ou poucos dias depois da festa ou, como presenciei, até mesmo no dia do evento. Esta urgência na postagem das imagens está, na maioria das vezes, relacionada aos familiares e parentes no Brasil. Através delas, estas pessoas tomam conhecimento (se não participam) da celebração do aniversário de seus sobrinhos, primos ou netos.

As comidas das festas de aniversário variam, como descrevi anteriormente, com a idade da criança e as redes de relacionamentos que estas vão formando nas escolas. Mas o que acontece quando a criança já está inserida, desde o nascimento, em redes de relações com brasileiros e norte-americanos? Fui à festa de aniversário de um ano de idade de Adam, fruto da união de uma brasileira, atendente de uma rede de fast food, e um policial americano. Na festa, realizada na casa do casal, havia uma divisão evidente entre os espaços ocupados por brasileiros e pelos americanos. Na sala, havia a mesa decorada com balões e enfeites temáticos da Arca de Noé, com o bolo e algumas balas. Nesta sala, estavam os parentes do pai da criança. Já na cozinha, onde se concentravam os brasileiros, estava a mesa com docinhos (brigadeiros, beijinhos e outras variações) e alguns cupcakes. Já na parte externa da casa, o tio americano da criança preparava hot dog, com pão e linguiça assada. O "Parabéns pra você" foi cantado em inglês e, posteriormente, em português.

Um fato comum a todas as festas de aniversário nas quais frequentei foi o fato dos convidados levarem doces e pedaços de bolo, ou até mesmo porções da comida do almoço ou jantar, para a casa. Isto é bastante comum também em festas de aniversário realizadas no Brasil. O que me surpreendeu bastante foi observar que os participantes, ainda durante a festa, muito antes do término da festa ou de deixarem o local, reservavam docinhos em um copo plástico para levarem para casa. Por vezes, isto gerava uma disputa pelos docinhos, que acabavam rapidamente devido a esta prática. Pela frequência em que vi isto acontecendo, parecia constituir em algo aceitável e compartilhado pelos convidados e pela família que oferecia a festa. Estes docinhos, segundo meus interlocutores, eram direcionados para os familiares que não puderam ir à festa, principalmente por estarem trabalhando. Desta forma, o consumo da comida compensava a ausência na festa. 
As festas de aniversário são momentos de comensalidade. O comer junto, como apontam diversos autores, conforma e reforça laços sociais. Como afirma Klaas Woortmann (2006), a comida não alimenta apenas corpos biológicos, como também "alimenta" e produz relações sociais. No entanto, de acordo com minhas observações e participação em festas de brasileiros em Boston, a comida que é servida e consumida apresenta um aspecto importante nestes eventos: o compartilhar a comida, assim como o que é compartilhado, estão interligados. A escolha sobre qual comida servir - como cookies e hot dog, ou os docinhos e salgadinhos - evidenciam que estes quitutes estão direcionados aos convidados a que se destinam, sejam estes os brasileiros com saudades dos brigadeiros, ou as crianças americanas acostumadas às festas celebradas com pizzas. Neste sentido, a materialidade da comida, com sua sensorialidade - e não apenas o comer junto - tem papel preponderante na interação social nos momentos de festividade.

\section{Celebrações "nacionais": Festival da Independência e Festas Juninas}

As festividades são momentos propícios para o encontro interétnico. A historiadora Donna Gabaccia conclui que os festivais de comidas étnicas apresentam o objetivo de comunicação da “"minoria', os grupos étnicos, com o mainstream da sociedade" (Gabaccia, 1998: 193). Nas festas em que participei, nas quais havia a presença de americanos, estes eram constantemente observados pelos brasileiros, principalmente quando comiam a "comida brasileira". Este consumo era comentado com certo orgulho e com afirmações sobre a superioridade da "comida brasileira". Através deste consumo, os imigrantes apresentavam, de certo modo, que eram aceitos pela sociedade local e como se fosse estabelecido um canal de comunicação entre grupos socioculturais distintos.

Baseado no conceito de "intertextualidade cultural” de Bruce Albert (1995), Ribeiro considera que as festas são momentos estratégicos que compreendem um processo dialógico através do qual é expressa a etnicidade (Ribeiro, 1998). Albert considera que esta intertextualidade cultural é formada tanto pelos discursos e retóricas pelas quais o grupo dominante constrói os "outros" (o autor centra sua análise no contexto do contato interétnico entre "brancos" e "índios"), quanto da autodefinição que estes últimos fazem deles mesmos. Deste modo, a autorrepresentação dos grupos 
étnicos seria resultado da intersecção da imagem que eles apresentam do "outro" quanto da sua própria imagem espelhada no "outro" (Albert, 1995).

Analisando a celebração do Dia da Independência do Brasil realizado em San Francisco, na Califórnia, Ribeiro descreve características típicas de cerimônias oficiais. Estas também estão presentes no Festival da Independência do Brasil em Boston, como o hasteamento da bandeira brasileira e a execução do hino nacional na prefeitura da cidade. Neste sentido, símbolos e rituais próprios do Estado-Nação elaboram a ideia de pertencer a uma nação (Ribeiro, 1998: 9). Esta "cerimônia cívica", no entanto, é acompanhada por poucos americanos (restringiam-se a autoridades políticas da cidade, como representante do prefeito) e poucos brasileiros, como lideranças da comunidade e os organizadores (ONGs voltadas ao atendimentos de imigrantes brasileiros no Estado de Massachusetts), com o apoio do Consulado Brasileiro e o patrocínio de uma empresa que realiza remessas internacionais de dinheiro e, por isso, tem interesse em atividades de grupos migrantes.

A participação de brasileiros ocorre de modo mais efetivo no festival ao ar livre, que ocorreu em um parque da cidade. Lá, há atividades para as crianças (passeio de pônei, brincadeiras com balões, desenhos e pinturas no rosto), mesas com informações sobre saúde e outros assuntos, exposições de artistas brasileiros, como pintores e músicos (principalmente, samba) e apresentações de capoeira. Durante toda a semana, há ainda apresentações de filmes brasileiros em diferentes locais da Grande Boston.

A comida "típica" tem um lugar de destaque no festival ao ar livre. As barracas são de proprietários brasileiros acostumados a vender comidas em festas brasileiras, e de um restaurante e churrascaria, que vendia prato com churrasco, arroz e salada. Este mesmo restaurante destinava uma barraca especialmente voltada aos americanos, com a venda de hamburgers e hot dogs. Havia também uma barraca de comidas da cooperativa de housecleaners que vendia comidas como forma de arrecadar dinheiro para atividades do grupo. Entre estas comidas, estava mingau de milho verde, milho cozido, salada de frutas, sanduíche natural e pamonha. Esta última rapidamente se esgotou, em menos de uma hora de festa. A grande procura era justificada pela dificuldade em se preparar pamonha na região. Minhas interlocutoras me explicaram que o milho "americano" era mais doce que o brasileiro e não tinha consistência suficiente para preparar o quitute. Duas housecleaners encontraram "milho brasileiro" em uma fazenda localizada a uma hora de carro de Boston, que o produz uma vez ao ano. 
A fila de espera para comprar "churros do Brasil" também era grande. Além destas comidas, era vendida ainda uma grande diversidade de comidas, como churrasquinho, cachorro-quente self service (com opções como vinagrete, milho, ervilha etc.), macarrão na chapa, cocada, acarajé, empadão, torta de camarão, torta de frango, torta de bacalhau, bolos, caldo de cana e coquetéis de frutas (fruit cocktails) em uma barraca chamada "Porto Seguro".

O Festival também é uma oportunidade de negócios para distribuidores de produtos brasileiros. Em uma das barracas, eram vendidos pacotes de fubá, polvilho azedo, polvilho doce, sal grosso, feijão preto, feijão carioquinha, milho de pipoca, canjica amarela, canjica branca e arroz branco asiático (o mais consumido entre meus interlocutores).

Há repercussões do festival na imprensa local - brasileira e nos principais jornais de Boston, corroborando as afirmações de Ribeiro (1998) de que estas festas difundem imagens do Brasil e dos brasileiros nos Estados Unidos. Em entrevista ao site de notícias locais, a presidente de uma das instituições organizadoras do evento explicou que o maior objetivo do festival era o de fortalecer a comunidade de brasileiros no estado de Massachusetts, além de aproximar a segunda geração de brasileiros às raízes brasileiras. De fato, o maior público do festival é de brasileiros, ainda que os convites para o evento sejam bilíngues (português e inglês). Neste sentido, a festa aparece como "congregador da população migrante em sua diversidade, que sejam imediatamente funcionais para o estabelecimento de redes de solidariedade ou para a formação ampla de um sentido de "comunidade imaginada" em um contexto de relações interétnicas" (Ribeiro, 1998: 3). Ainda que haja este aspecto congregador, a heterogeneidade - sotaques, modos de falar e fenotipia, principalmente, a cor da pele dos brasileiros é sempre percebida e destacada nos comentários e conversas informais dos participantes destes eventos.

As festas juninas também congregam a população migrante em sua diversidade, utilizando símbolos comuns a praticamente todos os brasileiros: música (forrós e músicas sertanejas), quadrilha, fogueira, bandeirinhas e comidas "típicas". Organizadas pelas igrejas católicas da Grande Boston, elas acontecem com hora marcada - a de início da festa e a de encerramento, por exigências das normas de segurança das prefeituras. A festa junina de Everett, por exemplo, aconteceu das cinco da tarde às onze da noite. Nesta festa junina, assim como na de Allston, boa parte da comida acabou antes do final da festa: na primeira, por volta das dez da noite; na segunda, ainda antes 
das nove horas. A comida é preparada principalmente por voluntários ligados às igrejas, e o dinheiro arrecadado é usado em atividades destes grupos. Estes voluntários têm que lidar também com a rigidez da fisscalização sanitária de fiscais da prefeitura de Boston, com o uso de luvas, aventais e toucas, além de normas específicas para o armazenamento das comidas. Estas eram variadas e faziam parte do repertório culinário das festas compartilhados pelos brasileiros, com poucas variações: churrasquinho, milho verde, cachorro quente, canjiquinha (doce), canjicão (caldo salgado), pipoca, amendoim, pastel, quentão e doces. Assim como os voluntários, os participantes das festas também tinham que obedecer as leis locais e lidar com a rígida fiscalização: o quentão e outras bebidas alcoólicas poderiam ser consumidas apenas no espaço da festa, não podendo ser levada para as ruas, o que era constantemente lembrando pelos organizadores aos participantes, sob a pena da festa ser cancelada pela polícia.

Tanto no festival da independência quanto nas festas juninas, um conjunto de elementos forma um ambiente sensorial que remetem ao Brasil ou à brasilidade: o apelo visual da decoração, a sonoridade da música e os sabores e cheiros das comidas. Esta última é uma das maiores preocupações dos organizadores das festas e uma das grandes expectativas do público, ainda que "não sejam iguais às do Brasil", caracterizando-se como mímesis (Taussig, 1993). Nas duas festas, muitas comidas esgotaram-se rapidamente, e não eram compradas apenas para serem consumidas na hora - vários participantes levaram quitutes para casa, para consumo próprio e para aqueles que não puderam comparecer à festa. Uma de minhas interlocutoras, ao comprar e sentir o cheiro de um pastel de carne na festa junina me confidenciou: "isso me dá saudade".

\section{Religião e comida: a comensalidade em Igrejas}

Uma antropóloga ou um antropólogo que etnografa imigrantes brasileiros nos Estados Unidos, principalmente no Estado de Massachusetts, dificilmente escaparia das igrejas brasileiras, ou as que oferecem missas e cultos em português. A presença destas igrejas é marcante na paisagem de muitas cities e towns onde os brasileiros se concentram (Marcus, 2009), mas é também perceptível nos meios de comunicação étnicos, como rádios e jornais impressos. Elas são ainda assuntos recorrentes nas conversas entre brasileiros, evidenciando que fazem parte do cotidiano de muitas destas pessoas. 
Além de serem destinadas à prática religiosa, as igrejas oferecem seus espaços físicos para a realização de diversos eventos não-religiosos, como reuniões de militantes em prol da reforma migratória, workshops sobre alimentação e saúde, reuniões de comitês para realização de aulas de português para filhos de brasileiros, vacinação da comunidade contra o vírus H1N1 etc. As Igrejas Católicas das comunidades de Everett, Allston e Framingham possuem Centros Comunitários que prestam assistência social aos imigrantes brasileiros.

As Igrejas também se tornam lugares privilegiados para os antropólogos que pesquisam as relações entre comida e religião. Como apontam estudos antropológicos clássicos, cosmologias religiosas apresentam prescrições e proibições sobre o que se deve ou não comer e sobre como, com quem e quando comer [ver, por exemplo, o estudo de Mary Douglas sobre o Levítico (1966)]. No caso específico das práticas alimentares de imigrantes brasileiros em Boston, as Igrejas chamam a atenção pela realização frequente de refeições (almoços, jantares, cafés da manhã) e festas onde as comidas apresentam papel fundamental, como mostrarei mais adiante. A atuação de Igrejas junto a imigrantes e seu papel no fluxo migratório também têm sido tema freqüente de pesquisas sociológicas e antropológicas.

A religião acompanha o processo migratório, como apontam Portes e Rumbaut (2006). Segundo os autores, a religião ajuda os imigrantes a superar os traumas da partida e o início do estabelecimento, proteger os imigrantes contra discriminação e ataques externos e "suavizar" a aculturação no novo meio. Ainda de acordo com estes autores, apesar de não determinar os modos de incorporação, as ações de comunidades religiosas podem afetar a influência destes fatores.

O significado da religião é analisado por Portes e Rumbaut, estudiosos de grupos migrantes, a partir das obras clássicas de Durkheim e Weber. A partir destas perspectivas teóricas, os autores entendem que a religião é compatível com o papel da sociabilidade em evitar os perigos da anomia e sustentar a coesão moral e controles normativos, como concluem os estudos clássicos de Durkheim. Além disso, seguindo teoria formulada por Weber, Portes e Rumbaut destacam que a convicção religiosa tem papel importante em guiar a ação humana e promover grandes processos de mudança, e observam que há consequências econômicas não esperadas da crença religiosa em nível individual e coletivo. 
Unindo estas duas perspectivas sociológicas clássicas, Hirschman (2007) resume a função da religião para os imigrantes em três palavras: refúgio, respeito e fontes. ${ }^{7} \mathrm{O}$ primeiro refere-se à proteção e ao conforto proporcionados aos recém-chegados, que enfrentam o estágio traumático do estabelecimento em um novo país. O segundo seria compatível com a perspectiva durkheimiana da anomia: a religião protegeria os imigrantes da perda de orientação normativa e do sentido de autovalor. ${ }^{8}$ Já o último está relacionado às consequências econômicas da filiação religiosa apontada por Weber neste sentido, constitui uma fonte de recursos para recém-chegados que reafirmam suas crenças religiosas ou estão à procura de uma.

Os Estados Unidos são um país onde há uma grande variedade de instituições religiosas, o que foi apontado por Portes e Rumbaut (2006) como uma consequência da inter-relação entre fé e processo de incorporação de imigrantes provenientes de diversas partes do mundo. Freston (2008) lembra, no entanto, que a grande maioria destes imigrantes são cristãos, e em menor número hindus, muçulmanos ou budistas. Neste sentido, o fluxo de imigrantes tem levado a uma pluralização de variantes cristãs, e não propriamente a uma pluralização de religiões de uma forma geral.

A presença de igrejas evangélicas entre brasileiros é uma das características mais visíveis deste movimento migratório. Segundo Freston (2008), em geral, a Igreja Católica encontra na diáspora dificuldade similar a que tem no Brasil em acompanhar os movimentos populacionais. O autor afirma que o Catolicismo tem dificuldades em periferias urbanas e em regiões agrícolas de fronteiras, precisamente os locais onde ocorre grande parte dos movimentos populacionais (Freston, 2008: 263). Como Freston (2008) mostra, embora alguns brasileiros pratiquem sua religiosidade em contextos nãobrasileiros, a maioria dos imigrantes vai a cultos ou missas destinadas a brasileiros.

A presença de igrejas católicas portuguesas precedeu as brasileiras em Massachusetts, devido ao fluxo de imigrantes portugueses ser mais antigo na região. Mas, com o estabelecimento de um número maior de imigrantes brasileiros no estado, missas brasileiras passaram a ser celebradas, o que revela que não apenas a língua é um elemento importante, como também os espaços de ajuda e assistência, que são ainda mais importantes para os que vivem no país indocumentados. Amorim, Dias e Siqueira

\footnotetext{
${ }^{7}$ Em inglês, o autor refere-se a três Rs: refuge, respect e resourses.

8 De forma semelhante, Tedesco (2010) sugere que a religião tende a proporcionar mais coesão e segurança aos imigrantes. Entrevistando imigrantes brasileiros em igrejas neopentecostais e evangélicas na Itália, o autor aponta que seus sujeitos de pesquisa veem as igrejas como espaços de ajuda, assistência e compreensão, que são ainda mais importantes para os que vivem no país clandestinamente.
} 
(2008) mostram, em pesquisa realizada em Governador Valadares, que as igrejas emigrantes oferecem suporte não somente para os brasileiros que migraram nos Estados Unidos, como também para os familiares dos emigrados que permaneceram no Brasil. O mesmo ocorre em igrejas evangélicas em Portugal, segundo o autor, onde cultos brasileiros são celebrados tendo em vista a participação de imigrantes brasileiros (Freston, 2008).

O padre da Igreja Católica de Allston contou-me que as missas celebradas em português têm uma presença maior de brasileiros do que as celebrações em inglês - em torno de 300 a 350 de brasileiros, contra pouco mais de 20 americanos por missa. Estas observações indicam que a presença de brasileiros estaria revitalizando as Igrejas Católicas na região. A partir de contatos estabelecimentos a partir das redes sociais nas quais estive inserida, participei mais intensamente de atividades de duas igrejas: uma Católica e outra Batista. Nesta última, principalmente no outono e inverno, eram realizados almoços após os cultos nas manhãs de domingo, e um lanche após o culto de domingo à noite. Além disso, havia jantares nas atividades das chamadas "células" - um encontro de fiéis na casa de uma família para estudo bíblico e orações. Já na Igreja Católica, participei como voluntária em festas juninas, e frequentei almoços aos domingos em comemoração ao Dia dos Pais e Thanksgiving. Em outras Igrejas Católicas, era comum também a realização de cafés e lanches antes ou após as missas. ${ }^{9}$

As comidas e os costumes tradicionais em Igrejas e templos étnicos contribuem para reforçar os relacionamentos entre imigrantes (Hirschman, 2007: 393). Os momentos de comensalidade são momentos de encontros entre imigrantes, que ajudam a criar e fortalecer vínculos sociais. Neste sentido, as refeições em comum dariam uma sensação de conforto aos imigrantes, especialmente aos recém-chegados, auxiliando-os a se inserir em círculos sociais.

A comida "brasileira" servida nas refeições atua como um fator fundamental nestes momentos de sociabilidade, pois ajuda a estabelecer um sentido de identificação

\footnotetext{
${ }^{9}$ Martes e Rodriguez (2004) observam que "as Igrejas protestantes brasileiras em Massachusetts criam de modo geral mais oportunidades de contato social entre seus membros que as igrejas católicas, e ao fazer isto tornam-se o principal locus de socialização e sociabilidade para seus fiéis. Enquanto a maioria dos membros das Igrejas protestantes se reúne toda semana numa refeição comunal, que é realizada após os cultos, as igrejas católicas promovem apenas alguns poucos eventos durante o ano: Dia dos Namorados, Proclamação da Independência, Nossa Senhora de Aparecida etc." Os autores observam que diferenças podem ser percebidas na estrutura física dos prédios das igrejas católicas e as protestantes, sendo que esta última ofereceria maior e melhor espaço e investiria maiores recursos em reformas para a socialização dos fiéis. Martes e Rodriguez sugerem que empreendedores brasileiros em Massachusetts procurariam as Igrejas Protestantes como forma de se inserirem em redes sociais e aumentarem seus negócios.
} 
comum entre aqueles que a compartilham. Minhas observações sobre a comida em festas de brasileiros na Grande Boston corroboram as conclusões da antropóloga inglesa Diana Mata Codesal, que estudou a alimentação de imigrantes equatorianos vivendo na cidade espanhola de Santander (Codesal, 2010). A autora explica que a comida consumida por seus sujeitos de pesquisa estava inserida em diferentes lógicas dependendo do contexto em que era preparada e consumida. No dia-a-dia, a comida preparada era espanhola (diferentemente da alimentação de meus interlocutores, que era composta, majoritariamente, de comida "brasileira") e era considerada comum. Já a comida equatoriana, feita em ocasiões especiais, adquiria o status de comida especial. Segundo a autora, através do compartilhamento de comida com aqueles vistos como iguais, estes imigrantes estavam rememorando. Esta comida tinha, de acordo com Codesal, o poder de agir como um gatilho para re-membering, para fazer as pessoas, ao mesmo tempo, sentirem-se como grupo e tornarem-se significantes uns para os outros. Desta maneira, os migrantes utilizavam comida de seu país de origem em ocasiões especiais para (re)criar ligações humanas no novo meio (Codesal, 2010).

As refeições em comum promovem momentos de conversação que conformam os laços entre estes sujeitos, segundo Simmel. Para este autor, “conversa é a realização de uma relação que, por assim dizer, não pretende ser nada além de uma relação - isto é, na qual aquilo que usualmente é a mera forma de interação torna-se seu conteúdo autossuficiente". É por isso que o autor entende que "a conversa é a forma mais pura e elevada de reciprocidade" (Simmel, 1983: 177). Segundo Simmel, no dia-a-dia, as pessoas conversam sobre conteúdos que querem conversar ou pretendem entender. Em reuniões sociais, no entanto, conversam por conversar. Deste modo, "a sociabilidade apresenta talvez o único caso em que a conversa é o legítimo propósito de si mesma”. Embora a conversação seja uma forma sociológica, seu conteúdo não é menos importante, pois deve ser atraente e interessante. É fundamental, entretanto, que nenhum conteúdo sobressaia, para que a conversação seja um fim em si mesma. Esta trivialidade do conteúdo das conversas também é importante, de acordo com Simmel, durante as refeições:

No entanto, tudo isso deve ser explicado também por uma praticidade fisiológica, que exige desembaraço nos movimentos e tranquilidade espiritual ao comer, Isso exprime na linguagem do corpo o nexo sociopsicológico que aqui deu lugar à realização social de uma carência muito primitiva, garantindo sua expansão segura, sem dúvida sem se desprender totalmente de sua base, mas, através da qual alçou à esfera de uma atratividade humana superior, espiritual. E, portanto, totalmente 
equivocado reclamar da banalidade das conversas típicas da mesa de jantar. A conversação donairosa à mesa - mantida sempre em um certo grau de generalidade $\mathrm{e}$ distante de intimidades - não deve nunca tornar esse fundamento totalmente insensível, porque a facilidade 196 evanescente e a graça do jogo de superficialidades se manifestam apenas quando se mantém esse seu caráter (Simmel 2004: 164).

O momento de conversação propiciado pelas refeições após os cultos foi destacado pela esposa do pastor responsável pela organização e preparo das comidas:

Eu acho que é um momento de complementação. Porque o pessoal chega em cima do horário do culto. Então vem, sobe, o culto já tá começando, participa. Então a hora que desce, é o momento que o pessoal tem pra ficar junto, pra estar conversando. Então é uma complementação de lá de cima. A gente até sofre porque o nosso espaço é pequeno. Então o pessoal desce, vê fila, aí vai embora. (Letícia)

Durante os lanches após os cultos, as pessoas permanecem sentadas ou em pé conversando enquanto comem pastéis, coxinhas, ou tomam caldos (mais servidos em períodos de maior frio). Durante os almoços de domingo após o culto da manhã, a falta de mesas acaba propiciando momentos de maior contato entre os fiéis, como destaca Letícia: “As pessoas forçosamente tem que sentar junto (a mesa com seis lugares), e aí acaba conversando." Apesar de as conversas superficiais, sem profundidade, fazerem parte dos momentos de comensalidade que observei nas Igrejas, estas refeições também promovem momentos de aprendizado social semelhante ao observado por Machado em relação aos churrascos entre brasileiros em Portugal:

O churrasco opera como um drama que distensiona a vida cotidiana marcada por conflitos no local de trabalho, pelo racismo a que estão sujeitos, pela insegurança da ilegalidade etc. o churrasco como evento social tem significados múltiplos e, numa das dimensões, é um lugar de proteção coletiva, uma válvula de escape. Nesse sentido, é um lugar de aprendizado simbólico efetivo, no qual recém-chegados descobrem tanto as sistemáticas opressões a que os brasileiros estão sujeitos, como as formas de desvio e resistência às mesmas situações. Aprendem argumentos que vão usar normalmente como se fossem seus, tais como as formas mais usuais de desculpas, as estratégias para contornar as broncas de chefes portugueses, como responder aos comentários desagradáveis que costumam ouvir etc. (Machado, 2001: 213)

Nas Igrejas, há encontros entre brasileiros provenientes de diferentes camadas sociais e situação migratória. É comum, durante as refeições, principalmente nas que participei entre fiéis da Igreja Batista, aconselhamentos sobre trabalho e solicitações de ajuda. Presenciei, por exemplo, um brasileiro indocumentado pedindo emprego a outro brasileiro com cidadania americana que tinha uma empresa de construção civil. Ou ainda um brasileiro indocumentado pedindo orientações jurídicas a outro brasileiro com Green Card que trabalhava como advogado. Os momentos de comensalidade nas Igrejas oferecem oportunidades de contatos entre brasileiros que possibilitam sua 
inserção em redes sociais e também aprendizado social estratégico para seu estabelecimento e sucesso em Boston.

Além disso, observei que estes eventos constituem-se em importantes mercados matrimoniais, em que os solteiros têm a possibilidades de encontrarem possíveis companheiros amorosos. Com a desconfiança que cerca os imigrantes e a suposta dificuldade em se casar com brasileiros em Boston, relatada pelos sujeitos de pesquisa, as refeições e festas em Igrejas ofereceriam oportunidades mais seguras para se encontrar um parceiro considerado adequado.

Se, por um lado, as refeições em comum e as atividades que envolvem seu preparo atuam no reforço de laços sociais e no estabelecimento da coesão em grupo, por outro lado, elas também são momentos em que conflitos são evidenciados entre seus membros. Observei, por exemplo, demonstrações de animosidades entre pessoas durante o preparo de comidas para a Festa Junina de uma Igreja Católica. Trabalhando como voluntária nesta festa, percebi que havia reclamações e acusações mútuas entre grupos divididos para prepararem determinadas comidas, como espetinhos de churrasco, pastéis, cachorro-quente, entre outros. Em outro momento, em um almoço da Igreja Batista, presenciei comentários contra alguns fiéis que se opunham a projetos do pastor a serem executados no prédio da Igreja. Neste sentido, preparo e consumo das comidas não apenas reforçariam vínculos sociais como também expressariam conflitos, que, seguindo as formulações de Simmel (1983), são parte da vida social. ${ }^{10}$

As igrejas propiciam oportunidades de encontro entre brasileiros não apenas em celebrações de datas comemorativas no Brasil, mas também no Thanksgiving, ou Dia de Ação de Graças, comemorado na penúltima quinta-feira do mês de novembro, considerado um dos feriados mais tradicionais e importantes dos Estados Unidos. A Igreja Católica organizou um almoço para os brasileiros, no qual cada participante ou família deveria contribuir com um prato. Foram levados arroz, feijão, saladas verdes, salpicão, arroz tropeiro, sobremesas diversas (tortas, pudins e sorvetes), além de perus assados - comida típica da data, conhecida popularmente como "turkey day", ou "dia do peru" - oferecidos pelos padres católicos e norte-americanos da igreja. Segundo o membro da igreja que assou os perus, estes foram preparados "do jeito brasileiro", que

\footnotetext{
${ }^{10}$ Para Simmel, o conflito é uma forma de interação que pode resolver dualismos divergentes. Neste sentido, na abordagem simmeliana, o conflito, ao contrário da indiferença, tem aspectos positivos, pois pode potencialmente solucionar a tensão entre divergentes (Simmel, 1983).
} 
ele explicou como contendo maiores quantias de sal do que os preparados por americanos, além de temperos, como alho.

Muitos dos brasileiros que participaram do almoço iriam a outras reuniões de amigos ou familiares após a refeição, pois era um dos raros dias de folga para a maioria dos imigrantes, com o fechamento da maioria das lanchonetes e estabelecimentos comerciais. Uma brasileira contou-me, após almoçar, que estava "pronta" para ir ao almoço oferecido por seus patrões americanos: "lá eu só como um pouquinho, para não fazer desfeita". Segundo ela, a comida preparada pelos americanos era "sem gosto", e deveria ser provada apenas em sinal de respeito aos anfitriões. Recusar a comida poderia significar constrangimentos e recusa de vínculos sociais, que eram estratégicos para a imigrante brasileira.

Não apenas os momentos de comensalidade constituem-se em momentos importantes para criar e manter os vínculos sociais nas Igrejas, como também presentear com comidas aqueles que ocupam cargos de poder nestas instituições religiosas. Nas Igrejas Batista e Católica em que participei mais ativamente, observei que recorrentemente o padre e o pastor, respectivamente, recebiam muita comida preparada pelos fiéis. O padre costumava receber convites para almoçar e jantar em casas de famílias de brasileiros, e constantemente recebia pedaços de bolo e marmitas com comidas de almoços e jantares. Segundo ele mesmo me contou, alguns fiéis costumavam conhecer suas preferências alimentares, e preparavam comidas especialmente para eles. Este conhecimento dos gostos individuais, assim como apontei em estudo realizado com mães de famílias de camadas médias e populares (Assunção, 2007), são utilizados de forma estratégica para expressar cuidado e sentimento em relação a pessoas próximas.

Presenciei situação semelhante com o pastor, cuja igreja cedia espaço para integrantes de outras nacionalidades que estavam se reunindo para celebrar cultos e organizar sua comunidade étnica para futuramente se transferirem para um espaço próprio. Durante o almoço após o culto, o pastor recebeu de um nepalês um prato cheio de comidas típicas. A esposa do pastor também me declarou "ser vítima" dos nepaleses por ter que experimentar a comida que preparavam. Apesar de declarar gostar da comida, por ser "caseira e bem-feita", e de apreciar experimentar coisas novas, ela destacou a grande quantidade de pimenta que continha. Tanto no caso do padre quanto do pastor e de sua esposa, a comida não podia ser recusada, mas deveria ser consumida, como um ato de estabelecimento e/ou reforço das relações. 
As refeições na Igreja Batista eram organizadas e preparadas pela esposa do pastor. Letícia, antes de mudar-se para Boston com o marido e os filhos, coordenou por três anos um buffet da mesma Igreja em Curitiba, que servia comida para casamentos e eventos realizados em um salão de festas com capacidade para 500 convidados. Neste buffet, todos eram voluntários, com exceção da cozinheira. Letícia elaborava o cardápio com a cozinheira, fazia lista de compras, circulava para ver se estava tudo pronto. Sua experiência, segundo ela, era "teórica". Quando chegou a Boston, percebeu que não tinha ninguém na "parte prática", então começou a se envolver. Logo após sua chegada, Letícia destacou o choque provocado com o encontro de "outros" brasileiros, eram provenientes de outros estados e camadas sociais no Brasil.

\begin{abstract}
Eu vim do sul, de Curitiba... então era um tipo de comida que a gente usava... quando cheguei aqui, o pessoal mais de Minas, né, a grande maioria... eu também me assustei... não depreciando nada, só questão de comparar. Lá a Igreja era num bairro nobre, então era um cardápio requintado. Então o pessoal falava que o buffet da Igreja não perdia em 200 nada para os dois grandes buffets da cidade, que eram o Clube Curitibano e o buffet do Batel. Então era do mesmo nível. Quando eu cheguei aqui, o primeiro casamento que eu fui, tinha feijão tropeiro, aipim frito, daí eu olhei, e pensei: nossa, é cardápio de casamento isso? Aí eu comecei a ver que era o paladar daqui tanto pela região da pessoa, quanto pela saudade daquele gosto. (Letícia)
\end{abstract}

As comidas das refeições na Igreja Batista são vendidas a preços inferiores aos cobrados em restaurantes e padarias. Em uma outra Igreja, que tinha café da manhã de domingo antes do culto, os fiéis costumavam levar as comidas (pães, pães de queijo, café, leite, biscoitos, manteiga etc). Neste caso, o café e as despesas eram partilhados. Nas festas da Igreja Católica que frequentei, ocorria algo semelhante: quando a refeição era preparada por apenas uma pessoa ou um pequeno grupo de pessoas, era cobrado um preço para cobrir as despesas. Em outras festas, quando cada participante ou família levava um prato para o almoço ou jantar, nada era cobrado pela comida. Segundo me explicaram interlocutores nas duas Igrejas, o dinheiro arrecadado nas festas e refeições era usado em projetos das instituições religiosas. Letícia disse-me que o fato de a Igreja cobrar pelas refeições era criticado por alguns de seus membros. Estes veriam as instituições religiosas como provedoras, o que entraria em conflito com a cobrança de dinheiro.

Outra coisa também: é uma cultura que eu não sei da onde que vem... que as pessoas parecem que é assim: lá fora, eu vou, eu como, eu pago, eu não reclamo, aqui na Igreja, não, que é isso? A gente fazia as coisas num preço mínimo, e ainda assim, as pessoas, sabe... por que a gente tem que pagar? Então eu achei essa dificuldade. Porque lá a gente trabalhava em nível profissional, com voluntários, mas era nível 
profissional. Mas aqui, como é na Igreja, então o pessoal acha que tem que ser de graça. Então é complicado. (Letícia)

Quando a comida é preparada em Igrejas, ela é feita geralmente por voluntários a maioria mulheres, mas também por homens, que são responsáveis especialmente pelo preparo de carnes, como o churrasco. Embora muitas pessoas frequentem os cultos, missas, refeições e festas realizados nas Igrejas, poucas pessoas efetivamente trabalham como voluntários em seu preparo. Como já coloquei anteriormente, o momento do preparo, além de ser um momento de sociabilidade, é também um momento de conflitos entre pessoas e grupos, como presenciei entre católicos que trabalhavam nas festas juninas. No entanto, a participação em trabalhos voluntários confere maior proximidade e vínculo entre os voluntários e aqueles que ocupam cargos de maior poder nas Igrejas. Apesar disso, há dificuldade, como coloca Letícia, em convencer os frequentadores da Igreja a se engajarem em trabalhos voluntários:

No Brasil, eu estava acostumada com o trabalho voluntário. Mas aqui, o pessoal vem com aquela mentalidade, de ganhar dinheiro. Então nada se faz de graça. (...) $\mathrm{O}$ meu marido diz sempre, que o pessoal que vem trabalhar como voluntário está dando duas vezes, porque está doando seu tempo e está deixando de ganhar alguma coisa. (Letícia)

No momento em que realizei a pesquisa de campo, apenas um casal mineiro estava ajudando Letícia a preparar a comida dos almoços de domingo. Segundo ela, por serem mineiros, queriam preparar pratos regionais, como tutu, polenta, moqueca mineira, frango com quiabo, e outros pratos típicos. Letícia, no entanto, diz buscar "um equilíbrio" para agradar pessoas vindas de outras regiões do Brasil. A comida preparada seria o resultado daquilo que confortaria a saudade dos imigrantes e dos preços e promoções dos alimentos de mercados da região.

A gente leva muito em conta o paladar das pessoas, do que as pessoas sentem saudades, e o preço das coisas da semana, da promoção da semana. Muitas vezes, a gente pensa: ah, domingo vamos fazer uma carne assim, mas daí chega lá e o frango tá na promoção. Então a gente muda e faz outra coisa. (Letícia)

É também levando em consideração a saudade e as preferências dos imigrantes que Letícia justifica a escolha por salgados, como coxinhas e pastéis, para o lanche, o que confirma a capacidade da comida em carregar lembranças e a sensação de familiaridade. 
O pessoal faz uma opção pelo salgadinho. É a coxinha e o não sei o que lá. Mas é aquilo que vai, encomenda para não sei quem, não sei aonde, que aí vai lá, faz, para as duas horas da tarde, já tá pronto para a festa que vai ser às seis da tarde. Não dá para fritar na hora, não? Hoje é mais comum, você vê mais gente fazendo, mas a oito anos atrás, eram poucas pessoas que trabalhavam com isso. Agora já é mais comum. Quando eu cheguei, na semana seguinte, eu já falei: 'vamos fazer cantina', porque era aquilo que o pessoal 'ai, que saudade, que vontade de comer uma coxinha'... ah, só tem uma padaria brasileira que é lá não sei aonde... era tudo mais longe. (Letícia)

Em relação às festas realizadas pela Igreja Católica para celebrar datas, como Dia das Mães, Dia dos Pais, Dia de Nossa Senhora Aparecida, Thanksgiving, entre outras, elas ocorreriam, segundo o padre, com o objetivo de preservar a cultura e também a culinária, além de divulgá-la nos Estados Unidos, embora, visivelmente, há a presença de poucos não-brasileiros nestas festas.

Primeiramente a festa acontece para preservar a cultura. Já começa daí: a cultura e o costume do nosso povo. Depois, o segundo ponto, é para preservar a questão culinária - o costume, a comida, o tipo da comida regional inclusive. Também, um terceiro ponto, é uma maneira de tornar a cultura mais conhecida dentro deste país. Tanto é que eles adoram a comida brasileira, a maioria adora...

Apesar desta tentativa de se preservar a culinária e de privilegiar as comidas que os imigrantes mais sentem falta, o que é comida brasileira não é consenso. Com um número bastante grande de mineiros em Igrejas, que segue a proporção de mineiros entre os brasileiros em Massachusetts, há, em muitos casos, a preparação de comidas de Minas Gerais em eventos realizados pelas Igrejas.

Estes pratos, embora bastante apreciados por alguns, são rejeitados por outros imigrantes. Observei que até mesmo a feijoada, considerada símbolo nacional (Fry, 1982), não é apreciada por todos os brasileiros nestes eventos nas Igrejas. Ainda que tenha sido servido apenas um tipo de comida, esta foi servida em duas versões, procurando a aceitação de um número maior de brasileiros. Em um dos almoços na Igreja Batista, foram servidos dois tipos de feijoada: uma light, sem carne de porco, e outra "completa". Podia-se notar uma divisão de gênero nestas versões: a primeira versão era perceptivelmente preparada e mais consumida pelas mulheres, enquanto a segunda era a preferida dos homens. Uma mulher sentou-se à mesa comigo, e comentou, enquanto comia a feijoada light: "eu nem gosto de feijoada, estou aqui por causa do pessoal". Saborear a refeição em comum, neste caso, era apenas uma oportunidade de criar e reforçar vínculos sociais, sem que pudesse se notar a vontade de comer algo da qual sentia saudade. 
A comida brasileira preparada e servida em refeições e festas das Igrejas é resultado de um processo de negociação. Há na Igreja Batista, por exemplo, a tentativa de alternar comidas variadas para contemplar a integração de membros provenientes de diferentes Estados brasileiros. Em algumas festas da Igreja Católica em que cada participante deve levar um prato para compartilhar, há a possibilidade de que diferentes pratos, de diferentes regiões, sejam incluídos.

A comida brasileira, portanto, é tão heterogênea quanto a população de brasileiros em Massachusetts. Mais do que celebrar ou manifestar a brasilidade ou identidade nacional, que seria comum aos brasileiros presentes a estes eventos, a procura por contemplar uma variedade mais ampla de comidas demonstra uma tentativa de aproximar da Igreja o maior número de participantes possível.

\section{Festival de Acarajé}

As festividades são também oportunidades de trabalho para muitos brasileiros em Massachusetts. Nas festas e festivais brasileiros, como o conhecido e grandioso Brazilian Day em Nova York e o Festival da Independência em Boston, muitos imigrantes trabalham em barracas de comidas. Na Grande Boston, há brasileiros que se especializaram em vender comidas nestas festas, o que requer licenças sanitárias e cursos específicos exigidos pelos governos locais, obtidos apenas por imigrantes documentados, e que empregam outros brasileiros, muitos deles indocumentados, para trabalhar nos dias dos eventos. Além disso, há padarias e restaurantes que oferecem serviços de buffets para festas, e também estabelecimentos comerciais especializados em comidas para estes acontecimentos. As festas e refeições servidas em Igrejas são também utilizadas como formas de arrecadar dinheiro para as instituições religiosas.

A comida, portanto, constitui-se um nicho de mercado para brasileiros na Grande Boston, que é voltado, na maioria dos casos, para a clientela brasileira. Através de relações de amizade de minha irmã, participei de um festival de acarajé, realizado por Maria, uma imigrante baiana. O objetivo era realizar encontros periódicos (quinzenais ou mensais), onde os participantes poderiam consumir, pagando uma quantia determinada, acarajé e vatapá. Apesar do projeto inicial, não tenho conhecimento de que outros festivais de acarajé tenham sido realizados após a primeira edição. A comida era preparada por Maria, que já estava nos Estados Unidos há pelo menos oito anos. O festival foi realizado no pátio da casa de uma de suas amigas, uma 
brasileira casada com um americano que se dizia apaixonado pela Bahia. Ele tinha pacotes de areia que trouxera de uma viagem às praias baianas. Ele descrevia esta areia como baby powder (talco de bebê) - segundo o americano, por serem tão finas quanto talco de bebê. Emprestou-me a areia para colocar em copos de vidros com conchas do mar, que serviram como decorações das mesas, e voltou a guardá-la após o término do festival. O dinheiro arrecadado no festival foi dividido entre Maria e a dona da casa.

Antes do festival, Maria nunca tivera experiência de vender acarajés. Ela trabalhava como vendedora em uma cantina de uma universidade. Durante a festa, ela foi questionada pelos participantes sobre não estar vestindo a vestimenta de baiana. Maria vestiu um jaleco branco e, por sugestão de sua amiga, alguns colares "para ficar mais parecida com uma baiana". Se o fato de ser proveniente do estado da Bahia lhe conferia legitimidade como baiana e, assim, legitimidade para preparar acarajés e vatapás, a falta da vestimenta era cobrada pelos participantes, o que não fazia parte das experiências e trajetória de vida de Maria, que disse se recusar a vesti-la. Concordo com as observações de Fajans (2008) de que o fato de uma mulher baiana preparar acarajé fornece autenticidade à comida mais do que os ingredientes ou modo de preparo.

A maioria dos participantes era do círculo de amizade de Maria e da dona da casa. Grande parte deles eram brasileiros, mas havia também americanos e um casal de cubanos, amigos do casal anfitrião. Alguns deles compareceram ao evento devido a relações de amizade, como duas amigas de Maria que não experimentaram a comida. Esta recusa em comer o acarajé foi feita discretamente, mas foi observada pela cozinheira, que já esperava este comportamento destas amigas, por serem "nojentas para comer".

Outros brasileiros, conforme me disseram, experimentaram acarajé pela primeira vez no festival. Para tentar agradar a todos e temendo rejeições, Maria fritou os bolinhos em óleo de dendê misturado em partes iguais de óleo de soja, "para não ficar muito forte". Nas análises de Fajans (2008) sobre a comida baiana, a autora sugere que o acarajé "encapsula a Bahia". De acordo com a antropóloga norte-americana, a figura da baiana, vestida com saias fartas e turbante, contrasta com a informalidade da cultura da praia, e é como uma "âncora com o passado", pois seria uma representação do que se transformou a sociedade do lazer dos dias de hoje. Ainda segundo Fajans, a figura da baiana seria um símbolo do que seria particularmente baiano e também um símbolo de um passado idealizado, pois representa o mais privilegiado dos escravos. A autora 
observa que, ao preparar o acarajé, a baiana integra vários fluxos culturais que convergiram na Bahia: o camarão, representativo dos frutos do mar abundantes do litoral baiano; o legado europeu do pão e do trigo; e a pimenta nativa. Assim como o acarajé vendido nas ruas da Bahia, o festival de acarajé realizado por minha interlocutora na Grande Boston também seria resultado de fluxos globais, mas com as transformações que toda forma de reprodução - ou de mímesis (Taussig, 1993) produz.

As imagens da cozinheira baiana e do acarajé faziam parte do repertório cultural compartilhado pelos brasileiros que compareceram ao festival, o que gerava expectativas em relação à forma como a comida e a própria cozinheira se apresentava. Mudanças visando a presença e aceitação destes brasileiros, no entanto, foram feitas: menos óleo de dendê, menos pimenta, acarajé e vatapá servidos em pratos, para ser comido nas mesas na presença de outros participantes. A decoração com conchas e areia também remetia às imagens do litoral da Bahia. As vestimentas de Maria, a cozinheira um jaleco branco - a distanciavam da religiosidade e das raízes africanas que marcam a figura da baiana nas ruas da Bahia. Se, como afirma Fajans, "comer certas comidas faz de você um baiano, e a comida é baiana por causa do lugar e de quem a preparou. Você come o que você é, mas você também faz/cozinha o que você é" (2008, tradução minha), entendemos que as mudanças que envolvem o preparo e a apresentação do acarajé também demonstram uma tentativa de controle das imagens associadas à comida e aos baianos. Este controle estaria relacionado tanto a uma estratégia em atrair clientes brasileiros assíduos, tanto como em buscar a aceitação destes, atenuando traços associados à baianidade que poderiam ser depreciativos. Neste caso, as mudanças ocorridas no processo da mímesis (Taussig, 1993) seriam intencionais e estratégicas para Maria, que estaria buscando estabelecer seu lugar através de uma particularidade a comida baiana - minimizando os elementos distintivos que os sujeitos consideram perigosos.

\section{Considerações finais}

Os relatos etnográficos presentes neste texto apontam a fecundidade de se pensar as práticas alimentares como vias leituras de processos socioculturais - neste caso, a imigração de brasileiros para os Estados Unidos. Permite, assim, analisar as múltiplas e complexas relações que estes sujeitos estabelecem entre si e a sociedade de destino. 
Sugere-se que considerar a comida a partir dos conceitos de agência e mímesis, além de outros aportes teóricos utilizados ao longo desta escrita, contribui para a construção de uma perspectiva na qual ela apresenta um protagonismo nos momentos de festividade e de encontros entre brasileiros. Evidencia-se, assim, sua participação ativa nestes eventos e seu estímulo aos sentidos por meio de sua materialidade, que provocam sentimentos e memórias.

\section{Agradecimentos}

Agradeço ao CNPq e à CAPES pelas bolsas de doutorado e doutorado-sanduíche no exterior, que permitiram a realização desta pesquisa.

\section{REFERÊNCIAS}

ALBERT, Bruce. Anthropologie appliquée ou 'anthropologie impliquée'. Ethnographie, minorités et développement. In: BARÉ, Jean-François (Org.). Les applications de l'Anthropologie. Un essai de réflexion collective depuis la France. Paris: Karthala, 1995. p. 87-118.

ALVES, Isidoro. A festiva devoção no Círio de Nossa Senhora de Nazaré. Estudos Avançados, São Paulo, 19(54), 2005. Disponível em:

$<$ http://www.scielo.br/scielo.php?script=sci_arttext\&pid=S010340142005

000200017\&lng=en\&nrm=iso $>$. Acesso em: 15 de maio de 2019.

AMORIM, Aparecida; DIAS, Carlos Alberto; SIQUEIRA, Sueli. Igrejas Protestantes como Espaço de Sociabilidade e Fé para os Familiares dos Emigrantes em Governador Valadares. Fronteiras, Dourados, 10 (18), 251-276, 2008.

APPADURAI, Arjun. Modernity at Large: Cultural Dimensions of Globalization. Minneapolis/Londres: University of Minnesota Press, 1996.

APPADURAI, Arjun. Disjunção e diferença na economia cultural global. In: FEATHERSTONE, Mike (Org.). Cultura Global: nacionalismo, globalização e modernidade. Petrópolis (RJ): Vozes, 1999. p. 311-327 
ASSUNÇÃO, Viviane Kraieski de. Nem toda receita é Mais Você: estudo etnográfico sobre consumo e recepção de programas televisivos de culinária em camadas médias e populares. Dissertação de Mestrado em Antropologia Social. UFSC: Florianópolis, 2007.

ASSUNÇÃO, Viviane Kraieski de. Onde a comida não tem gosto: uma análise do gosto como prática e interação. Revista Pós-Ciências Sociais, 13, 159-180, 2016.

BOYD, Monica. Family and personal networks in international migration: recent developments and new agenda. International Migration Review. 23(3):638-670, 1989.

CLARKE, Alison J. Consuming children and making mothers: birthday parties, gifts and the pursuit of sameness. Horizontes Antropológicos, Porto Alegre, v. 13, n. 28, Dezembro de 2007. Disponível em:

$<$ http://www.scielo.br/scielo.php?script=sci_arttext\&pid=S0104-

$71832007000200011 \& \operatorname{lng}=$ en\&nrm=iso $>$. Acesso em: 31 de março de 2019.

CODESAL, Diana Mata. Eating abroad, remembering (at) home. Anthropology of food [Online] , 7, 2010. Disponível em: $<$ http://aof.revues.org/index6642.html >. Acesso em: 31 de março de 2019.

DOUGLAS, Mary; ISHERWOOD, Baron. O Mundo dos Bens: para uma antropologia do consumo. Rio de Janeiro: Editora UFRJ: 2006.

FAJANS, Jane. Can moqueca just be fish stew? Anthropology of food [Online], S4, 2008. Disponível em: $<$ http://aof.revues.org/index3623.html>. Acesso em: 31 de março de 2019.

FRESTON, Paul. The Religious Field among Brazilians in the United States. In: JOUET-PASTRÉ, Clémence, BRAGA, Leticia (Ed.). Becoming Brazuca: Brazilian Immigration to the United States. Harvard University Press: Cambridge (MA), 2008. p. $255-270$

FRY, Peter. Para Inglês Ver: Identidade e Política na Cultura Brasileira. Rio, Zahar, 1982.

GABACCIA, Donna. We Are What We Eat: Ethnic Food and the Making of Americans. Cambridge: Harvard University Press, 1998.

GELL, Alfred. Art and Agency: an anthropological Theory. Oxford: University Press, 1998.

GER, Güliz; KRAVETS, Olga. Special and Ordinary Times: Tea in Motion. In: SHOVE, Elizabeth; TRENTMANN, Frank; WILK, Richard (Ed.). Time, Consumption and Everyday Life: Practice, Materiality and Culture. Oxford: Berg, 2009. p. 189-202

HIRSCHMAN, Charles. The Role of Religion in the Origins and Adaptation of Immigrant Groups in the United States. In: PORTES, Alejandro; DEWIND, Josh. (Ed.). 
Rethinking Migration: New Theoretical and Empirical Perspectives. Berghahn Books: New York/Oxford, 2007. p. 391-418

KRAIESKI, Viviane. Alimentando relações e marcando diferenças: Comida brasileira entre imigrantes brasileiros na Grande Boston. Sociedade e Cultura, 18, 41-54, 2015.

LAGROU, Elsje Maria. Caminhos, Duplos e Corpos: Uma abordagem perspectivista da identidade e alteridade entre kaxinawa. Tese (Doutorado em Antropologia).

Faculdade de Filosofia, Letras e Ciências Humanas. USP, 1998.

LIMA, Alvaro. Brasileiros na América. Boston, 2009.

MACHADO, Igor José de Reno. Identidade e Subordinação Ativa: uma etnografia dos imigrantes brasileiros no Porto. In: LIMA, Roberto Kant de. (org.) Antropologia e Direitos Humanos 3. Prêmio ABA/FORD. Niterói: Ed. UFF, 2001.

MARGOLIS, Maxine L. Invisible minority: Brazilians in New York City. Massachusetts: Allyn and Bacon, 1998.

MARCUS, Alan. (Re)creating places and spaces in two countries: Brazilian transnational migration processes. Journal of Cultural Geography, 26(2), 173-198, 2009.

MASSEY, Douglas. The social organization of migration. In: MASSEY, Douglas; ALARCON, Rafael; DURAND, Jorge; GONZÁLEZ, Humbert (Ed.). Return to Aztlan: the social process of international migration from Western Mexico. Berkeley, University of California Press, 1990. pp.139-171.

MARTES, Ana Cristina Braga; RODRIGUEZ, Carlos L.. Afiliação religiosa e empreendedorismo étnico: o caso dos brasileiros nos Estados Unidos. Rev. adm. contemp., Curitiba, 8(3), 2004. Disponível em:

$<$ http://www.scielo.br/scielo.php?script=sci_arttext\&pid=S1415-

$65552004000300007 \& \operatorname{lng}=$ en\&nrm=iso $>$. Acesso em: 15 de julho de 2019.

MAUSS, Marcel. Ensaio sobre as variações sazonais das sociedades esquimós. In:

MAUSS, Marcel. Sociologia e Antropologia. São Paulo: Cosac \& Naify, [1906] 2003. p. 423-506

MAUSS, Marcel. Ensaio sobre a dádiva: forma e razão da troca nas sociedades arcaicas. In: MAUSS, Marcel. Sociologia e Antropologia. São Paulo: Cosac \& Naify, [1925] 2003. p. 183-314

MILLER, Daniel. Material Culture and Mass Consumption. Oxford: Basil Blackwell, 1987.

MOERAN, Brian; SKOV, Lisa. Mount Fuji and the Cherry Blossoms: A View from Afar. In: KALLAND, A.; ASQUITH, P. (Ed.). Japanese Images of Nature: Cultural Perspectives. Surrey: Curzon Press, 1997. p. 181-205 
PORTES, Alejandro; RUMBAUT, Rubén. Immigrant America: a portrait. $3^{\mathrm{a}}$ ed. Los Angeles: University of California Press, 2006.

RIBEIRO, Gustavo Lins. Goiânia, Califórnia, vulnerabilidade, ambigüidade e cidadania transnacional. Série Antropologia, Departamento de Antropologia. Universidade de Brasília, número 235, 1998.

SAYAD, Abdelmalek. A imigração ou os paradoxos da alteridade. São Paulo: EDUSP, 1998.

SEREMETAKIS, C. Nadia. The Memory of the Senses: Historical Perception, Commensal Exchange and Modernity. Visual Anthropology Review, 9(2), 02-18, 1993.

SIMMEL, Georg. Sociologia da refeição. Estudos Históricos, Rio de Janeiro: Fundação Getúlio Vargas, 33, 159-166, 2004.

SIMMEL, Georg. O Estrangeiro. In: MORAES FILHO, Evaristo de (Org.). Georg Simmel. São Paulo: Ática, 1983.

ORTIZ, Renato. Mundialização e Cultura. 2. ed. São Paulo: Brasiliense, 1994.

TAUSSIG, Michael. Mimesis and Alterity. New York and London: Routledge, 1993.

TEDESCO, João Carlos. As igrejas evangélicas e neopentecostais no cenário da imigração brasileira para a Itália. Anais do $34^{\circ}$ Encontro Anual da ANPOCS. Caxambu, 2010.

WOORTMANN, Klaas. A Comida, a Família e a Construção do Gênero Feminino. Revista de Ciências Sociais, 29 (1), 103-30, 1986.

WOORTMANN, Klaas. O sentido simbólico das práticas alimentares. In: ARAÚJO, Wilma Maria Coelho, TENSER, Carla Márcia Rodrigues. Gastronomia: cortes e recortes. Brasília: SENAC, 2006. p. 23-55.

Recebido 22/10/2019

Aprovado 11/12/2019 